\title{
ALEA LACTA EST: \\ THE KAMPALA AMENDMENT ON THE CRIME OF AGGRESSION POST-2017: A RESPONSE TO KOH AND BUCHWALD
}

\author{
Andreas Zimmermann*
}

\section{Introduction}

Having embarked in 49 BCE on his long war against Pompey, Julius Caesar reportedly commented "alea iacta est" - events have passed a point of no return. ${ }^{1}$ With the adoption and uptake of the Kampala amendment on the crime of aggression the Rubicon has also been crossed with twenty-six states (i.e. merely four less than the required quorum ${ }^{2}$ ) having ratified the amendment. A significant further number of states have ratified the Rome Statute after the adoption of the Kampala amendment, ${ }^{3}$ posing the interesting question whether they ought to be counted towards that quorum.

After the January 1, 2017 deadline passes, the Assembly of States Parties of the Rome Statute (ASP) is empowered to decide to activate the Court's jurisdiction under Resolution RC/Res. 64 adopted at the review conference in Kampala in 2010. Given the amplitude of the prevailing majority within the ASP, as evidenced by the way the amendment was adopted in Kampala (i.e. by way of consensus), support for activation of the Court's jurisdiction concerning the crime of aggression will be strong.

Harold Koh and Alain Pellet are by no means the only authors or officials who, six years after the amendment was adopted, still dwell upon what ought to have been adopted in Kampala, and indeed whether it was a wise move to include the crime of aggression into the Rome Statute at the first place. ${ }^{5}$ Whether one likes it or not

* Professor of International and European Law at the University of Potsdam, Germany and Director of the Potsdam Centre of Human Rights.

Originally published online 02 March 2016.

${ }^{1}$ Gaius Suetonius Tranquillus, De Vita Caesarum, Book I: Divus Iulius, para. 32 (121); the full citation reads: "Tunc Caesar: 'Eatur' quo deorum ostenta et inimicorum inquitas vocat. Iacta alea est', inquit.'

${ }^{2}$ Those were, as of December 31, 2015: Andorra, Austria, Belgium, Botswana, Costa Rica, Croatia, Cyprus, CzechRepublic, Estonia, Finland, Georgia, Germany, Latvia, Liechtenstein, Lithuania, Luxembourg, Malta, Poland, Samoa, San Marino, Slovakia, Slovenia, Spain, Switzerland, Trinidad and Tobago, as well as Uruguay; for the current list see Amendments on the crime of aggression to the Rome Statute of the International Criminal Court, United NATIONS TREATY COLLECTION. As to possible further forthcoming ratifications of the Kampala amendment on the crime of aggression, see Status of ratification and implementation, THE GLOBAL CAMPAIGN FOR RATification AND IMPLEMENTATION OF THE KAMPALA AMENDMENTS ON THE CRIME OF AGgReSSiON.

3 Those are Cabo Verde (Oct. 10, 2011), Côte d’Ivoire (Feb. 15, 2013), Grenada (May 19, 2011), Guatemala (Apr. 2, 2012), Maldives (Sep. 21, 2011), Philippines (Aug. 30, 2011), Republic of Moldova (Oct. 12, 2010), Seychelles (Aug. 10, 2010), St. Lucia (Aug. 18, 2010), State of Palestine (Jan. 2, 2015), Tunisia (Jun. 24, 2011), as well as Vanuatu (Dec. 2, 2011), for the current list, see Rome Statute of the International Criminal Court, United NATIONS TREATY COLLECTION.

4 See Review Conference of the Rome Statute of the International Criminal Court, 31 May-11 June 2010, Official Records.

${ }^{5}$ Harold H. Koh and Todd F. Buchwald, The Crime of Aggression: The United States Perspective, 109 AJIL 257 (2015); Alain Pellet, Response to Koh and Buchwald's Article: Don Quixote and Sancho Panza Tilt at Windmills, 109 AJIL 557 (2015). 
(and this author continues to have significant reservations as to both the substance of the amendment and the procedure by which it was adopted ${ }^{6}$ ), the amendment will soon become a reality.

It is in light of this situation that instead of looking backward, this short piece will in a forward-looking manner, albeit briefly, analyze the options available and the challenges ahead for the various actors involved in the forthcoming process of activating the Court's jurisdiction. Those actors include: first, the ASP called upon to decide on the matter after January 1, 2017; second, the Security Council when deciding upon a referral of a situation under Article 13(b) Rome Statute once the crime of aggression forms part of the statutory acquis of the ICC; and, third, various categories of individual States depending on their specific situation vis-à-vis the Rome Statute and the Kampala amendment on the crime of aggression.

\section{Assembly of States Parties: Clarifying Outstanding Jurisdictional Issues}

Under Article 15bis(3) Rome Statute, as amended in Kampala, the Court's exercise of jurisdiction is subject to a decision to be taken after January 1, 2017 by the States Parties of the Rome Statute. Given that the text does not set a specific deadline or a precise date for such decision to be eventually taken, the States Parties have some leeway as to when exactly such decision will be made. Given the political will of at least a significant number of contracting parties within the ASP to activate the Court's jurisdiction as soon as possible, the times currently speculated on are the $16^{\text {th }}$ regular session of the ASP (i.e. in November/December 2017), or possibly a resumed $15^{\text {th }}$ session of the ASP which could take place in early 2017. This is (at least politically) contingent, however, on thirty states having become bound by the amendment in order for the Court to exercise its jurisdiction, with a further unresolved question of the significance for these purposes of post-Kampala ratifications of the Rome Statute.

When it does activate the Court's aggression-related jurisdiction, it would be helpful if the ASP were to confirm in its decision to activate the Court's aggression-related jurisdiction at least three questions raised by the wording of the provisions and understandings adopted in Kampala thereby providing some guidance to the Court and its organs in its future work on the crime of aggression.

The first concerns the meaning of the phrase "ratification or acceptance of the amendments." Article 15bis(2) of Rome Statute (and Article 15ter(2) Rome Statute) provides that "[t]he Court may exercise jurisdiction only with respect to crimes of aggression committed one year after ratification or acceptance of the amendments by thirty states Parties." The question is whether "ratification or acceptance of the amendments," as used in those provisions, (in contrast to the wording of Article 121(4) and (5) Rome Statute, which instead refers to the deposit of an instrument of ratification or acceptance) should be seen as implying that any such "ratification/acceptance" of the amendment under Article 15bis(2) Rome Statute refers to the amendment becoming binding for the ratifying/accepting state, rather than referring to the act of depositing the instrument of ratification or acceptance. ${ }^{11}$ This difference is relevant since, in accordance with Article 121(5) Rome Statute, any such ratification/acceptance only takes effect one year after the deposit of the instrument of ratification/acceptance. Hence, taking the wording of Article 15bis(2) Rome Statute at face value could possibly lead to a postponement of the Kampala amendment on the crime of aggression becoming effective.

${ }^{6}$ Andreas Zimmermann, Amending the Amendment Provisions of the Rome Statute: The Kampala Compromise on the Crime of Aggression and the Law of Treaties, 10 J. INT'L CRIM. JUST. 209, 209 (2012).

${ }^{11}$ For a more detailed analysis of this issue, see already Andreas Zimmermann \& Elisa Freiburg, Art. 15bis, in COMMENTARY ON THE Rome Statute of the International Criminal Court 741, MN 13 (Otto Triffterer \& Kai Ambos eds., 3rd ed., 2016). 
When it does activate the Court's aggression-related jurisdiction, it would be helpful also if the ASP were to also confirm in its decision the definitive answers to two further questions raised by the wording of the provisions and understandings adopted in Kampala thereby providing some guidance to the Court and its organs in its future work on the crime of aggression.

For one, the ASP ought to clarify whether states, including most recently the State of Palestine, which have acceded to the Rome Statute post-Kampala (or at least those States which might accede to the Rome Statute after the Court's aggression-related jurisdiction has been activated) without taking a position whether they intend to be bound by the Kampala amendments, have nevertheless ipso facto become bound by them in light of Article 40(5) Vienna Convention on the Law of Treaties ${ }^{12}$, as well as in light of the specificities of the treaty regime set up by the Rome Statute and the amendment process thereunder.

In any event, however, such states, having ratified the Rome Statute post-Kampala even without at the same time explicitly ratifying the Kampala amendment on the crime of aggression, are bound by it. This has the ensuing effect of the Court being able to exercise its aggression-related jurisdiction when the underlying act of aggression was committed by such state, unless it has made an opt-out declaration under Article 15bis(4) Rome Statute.

Besides, the ASP should clarify the complex questions of the interrelationship between the Court's temporal jurisdiction on the one hand, and of the "activation" of its aggression-related jurisdiction on the other, as laid out in Article 15bis/ter(2) Rome Statute (regulating the former) and in Article 15bis/ter(3) Rome Statute (regulating the latter), as further defined in Understanding 3 adopted by the negotiating states in Kampala as Annex III of the enabling Resolution RC/Res.6.

As is well-known, Understanding 3 provides that "in case of article 13, paragraph (a) or (c), the Court may exercise its jurisdiction only with respect to crimes of aggression committed after a decision in accordance with article 15bis, paragraph 3, is taken, and one year after the ratification or acceptance of the amendments by thirty States Parties, whichever is later." A correct interpretation, taking into account the combined effect of Article 15bis(2), Article 15bis(3) Rome Statute and Understanding 3, leads to the result that the Court will only be able to exercise its jurisdiction ratione temporis one year after the thirtieth ratification or acceptance has become effective and after the decision contemplated in Article 15bis(3) Rome Statute has been made. Besides, the Court's jurisdiction is then only exercisable with respect to crimes of aggression committed after the thirtieth ratification or acceptance has become effective and after the decision provided for in Article 15bis(3) Rome Statute has been made. A decision made by the ASP activating the Court's aggression-related jurisdiction could not only reconfirm this result, but could then also apply it to the specific time-frame, as it will then apply in light of the prevailing circumstances.

\section{Security Council: To Refer or not to Refer?}

Another issue relates to the role of the Security Council and, in particular, the question whether, when referring a situation, under Article 13(b) Rome Statute read in conjunction with Article 15ter Rome Statute, the Security Council might limit the Court's jurisdiction to genocide, crimes against humanity and war crimes, thereby excluding the Court from at the same time also eventually exercising jurisdiction as to the crime of aggression. ${ }^{13}$

12 As to the various arguments pro and contra such effect in light of the specificities of the treaty regime set up by the Kampala amendment, see Andreas Zimmermann, Does $19+11$ Equal 30?: The Nitty Gritty of the Law of Treaties and the Kampala Amendment to the Rome Statute on the Crime of Aggression, EJIL: TALK! (Nov. 27, 2014), as well as Zimmermann and Freiburg, supra note 11, at MN 14.

${ }^{13}$ See on this issue already Zimmermann and Freiburg, Art. 15ter, in COMMENTARY ON THE Rome STATUTE Of THE INTERNATIONAL Criminal CourT 765, MN 5 (Otto Triffterer \& Kai Ambos eds., 3rd ed., 2016). 
This question is not specifically addressed as such in Article 15ter Rome Statute. It ought to be noted, however, that under Article 13(b) Rome Statute to which Article 15ter(1) Rome Statute makes reference, the Security Council refers an overall "situation" rather than a specific crime. Accordingly, the Security Council might eventually be facing a dilemma. It can either decide to refer a situation as such, and by the same token enable the Court to exercise its substance-matter jurisdiction vis-à-vis the crime of aggression—an act which might be perceived by some (permanent) members of the Security Council as an encroachment upon the latter's prerogatives under the Charter of the United Nations. In the alternative, the Security Council may decide not to refer such a situation at all. Yet, this would come at the price of barring the Court from prosecuting any of the other crimes listed in Article 5 Rome Statute, unless the Court was in a position to exercise its treaty-based jurisdiction over those crimes, but had no jurisdiction over the crime of aggression, given the stricter jurisdictional limitations contained in Article 15bis(4) and (5) Rome Statute ${ }^{14}$, as compared to the general jurisdictional set-up of the Court under Article 12 Rome Statute.

Where in a given situation the Court is in a position to exercise its treaty-based jurisdiction over the crimes listed in Article 5(1)(a) to (c) Rome Statute, but not its treaty-based jurisdiction related to the crime of aggression due to the aggression-specific jurisdictional limitations contained in Article 15bis(4) and (5) Rome Statute, a Security Council referral under Article 13(b) Rome Statute in conjunction with Article 15ter(1) Rome Statute would, apart from also triggering a broader range of duties to cooperate with the Court, de facto amount to a partial referral of the crime of aggression. Given that most, if not all, permanent members of the Security Council have misgivings concerning the Kampala amendment on the crime of aggression, any such referral seems anyhow to be highly unlikely.

The Security Council might however be tempted to try to de facto exclude the Court from exercising its aggression-related jurisdiction even in case of a Security Council referral under Article 15ter Rome Statute by referring a "situation" defined in temporal terms, thereby only covering e.g. war crimes and crimes against humanity allegedly committed, but not a crime of aggression which might have previously taken place during the initial phase of a given armed conflict but outside of the temporal scope of the situation referred.

\section{States Parties and Third States: Making Critical Choices}

Perhaps the most important task it to analyze the legal parameters of the post-2017 options available for states. This is straightforward with regard to third states which have not ratified the Rome Statute, but complex with regards to States Parties.

As to the former group, Article 15bis(4) and (5) Rome Statute, as well as Understanding 2 e contrario, make clear that the Court is barred from exercising its aggression-related jurisdiction over nonparties to the Rome Statute unless a Security Council referral is forthcoming. Hence, there is no need for such states to take any action whatsoever.

With regard to States Parties of the Rome Statute, Article 15bis(4) Rome Statute provides that their nationals are subject to the Court's treaty-based aggression-related jurisdiction, whether the state has ratified the Kampala amendment or not (and indeed regardless of whether it ratified the Rome Statute prior to Kampala or thereafter). However, Article 15bis(4) Rome Statute also provides that any such state may opt out from the Court's treaty-based aggression-related jurisdiction. Nothing in the text of Article 15bis(4) Rome Statute would prevent even a state that has itself participated in bringing about the "activation" of the Court's treaty-based, aggression-related jurisdiction by way of its ratification or acceptance from "protecting" its own citizens from the

14 See inter alia Kirsten Schmalenbach, Das Verbrechen der Aggression vor dem Internationalen Strafgerichtshof: Ein politischer Erfolg mit rechtlichen Untiefen, 65 JuRISTENZEITUNG 745, 751 (2010) (Ger.), as well as Zimmermann and Freiburg, supra note 13, MN 5. 
Court's jurisdiction by submitting an opting-out declaration to the Registrar in accordance with Article 15bis(4) Rome Statute.

However, it is necessary to distinguish between parties to the Rome Statute not having ratified the Kampala amendment based on whether they ratified the Rome Statute prior to Kampala or only thereafter. As to the former group of states, significant doubts remain as to whether the opt-out procedure enshrined in Article 15bis(4) Rome Statute is in line with Article 121(5) Rome Statute, which, under the enabling resolution adopted at the Kampala Diplomatic Conference, constitutes the treaty provision providing for the entry into force of the Kampala amendments, and which provision obviously states that amendments only apply vis-à-vis those States Parties which have accepted them.15 Put otherwise, Article 15bis(4) Rome Statute, contrary to Article 121(5) Rome Statute, forces States Parties not willing to accept the Court's treaty-based, aggression-related jurisdiction to formally opt out of this jurisdiction, instead of simply allowing them to remain silent and rely on their nonacceptance of the amendment tout court. In light of this situation, states which take the position that the opting-out procedure as laid down in the Kampala amendments cannot be reconciled with the amendment provisions of the Statute, might, at any given moment prior to the critical date, declare that they simply do not feel bound by the amendment even without formally submitting an opt-out declaration. Such a declaration could be phrased with a sufficient degree of deliberate vagueness so as to be eventually interpreted by the Court, should the case arise, as an opting-out declaration under Article 15bis(4) Rome Statute. At the same time, it seems that states that have acceded to the Rome Statute after Kampala have thereby, albeit only implicitly, accepted the necessity to formally opt out from the Court's exercise of its treaty-based aggression-related jurisdiction in order to protect themselves from the Court doing so when it comes to their nationals or the crime of aggression allegedly having been committed on their soil.

In order to be valid, and in line with the object and purpose of Article 15bis(4) Rome Statute, any opting-out declaration must be made prior to the act of aggression rather than prior to the exercise of jurisdiction by the Court. ${ }^{16}$ In order to prevent states from misusing the opt-out option and in line with the concept of good faith, as applied by the International Court of Justice in relation to the termination, by the United States, of its declaration under Article 36(2) ICJ Statute in the Nicaragua case, it is submitted that a certain minimum period of time is required before such a declaration becomes effective. ${ }^{17}$

A state contemplating making use of the opt-out procedure under Article 15bis(4) Rome Statute ought also consider whether such State wants its declaration to be valid indefinitely, or for a limited time period only, given that such declaration may be revoked at any given moment. ${ }^{18}$

Finally, a state considering submitting an opt-out declaration under Article 15bis(4) Rome Statute should also contemplate whether such declaration ought to only cover one of the jurisdictional links provided for in Article 12 Rome Statute, i.e. the nationality of the perpetrator or the place of the offence, or both. While the wording of Article 15bis(4) Rome Statute, contrary to the one of Article 124 Rome Statute, is somewhat ambiguous as to whether indeed such a "partial" opt-out is possible, one cannot but note that an opting-out declaration under Article 15bis(4) Rome Statute limits the Court's otherwise existing treaty-based, aggression-related jurisdiction.

${ }^{15}$ For further details, see Zimmermann, supra note 6, at 220 et seq.; Kai Ambos, The Crime of Aggression after the Kampala, 53 GER. Y.B. INT'L L. 463, 504 (2010); Schmalenbach, supra note 14, at 750 et seq.; Zimmermann and Freiburg, supra note 11, at MN 27.

16 Ambos, supra note 15, at 505; Astrid Reisinger Coracini, The International Criminal Court's Exercise of Jurisdiction Over the Crime of Aggression-at Last... in Reach... Over some, 2 GoETTINGEN J. INT'L L. 745, 777 (2010); Zimmermann and Freiburg, supra note 11, at MN 29.

17 See mutatis mutandis Military and Paramilitary Activities in and against Nicaragua (Nicar. v. U.S.), Jurisdiction and Admissibility, 1984 ICJ REP. 392, para. 63 (Nov. 26), as well as Land and Maritime Boundary between Cameroon and Nigeria (Cameroon v. Nigeria), Preliminary Objections, 1998 ICJ REP. 275, para. 33 (June 11).

$18 \mathrm{On}$ this issue, see Zimmermann and Freiburg, supra note 11, at MN 32. 
This being the case, it seems to be appropriate to allow for a limited opting-out declaration to be made under Article 15bis(4) Rome Statute, ${ }^{19}$ third parties being protected against the exercise of the Court's treaty-based aggression-related jurisdiction anyhow already by virtue of Article 15bis(5) Rome Statute.

\section{Concluding Observations}

As regards the crime of aggression under the Kampala amendment, the die has probably been cast: alea iacta est. Still, states involved in the process will, one way or the other, be it as members of the ASP, be it as members of the Security Council, or finally be it as an individual State Party, have to make critical choices. It is those choices that will really determine decide whether, and if so to what extent and in what way, the Kampala amendment will have an impact on the fabric of international law. It is only then that it will be possible to decide whether indeed it was a good choice to extend the Court's jurisdiction to cover the crime of aggression at the first place.

19 See also, Carrie McDougall, The Crime of Aggression under the Rome Statute of the International Criminal CourT 267 (2013). 